\title{
照明計算における電子計算機の利用 $†$
}

\section{1.はじめに}

最近, 照明工学の分野にもディジタル電子計算機が利 用されることが多くなった. 主として非常に繁雑な計算 を高速化しな場合が多いが，従来考えられなかった新し い分野を開拓した場合も現われてきている。

照明計算の分野でディジタル電子計算機の利用されて いるのは主として次のようである。

1. 照明器具眍光データの処理

2. 野外照明の設計 $\left\{\begin{array}{l}\text { 道路照盟 } \\ \text { スホ照明 }\end{array}\right.$

3. 公内照明の問題 $\left\{\begin{array}{l}\text { 相互反射の計算 } \\ \text { ましさの計算 }\end{array}\right.$

4. 色彩計算

5. 黑体の黑さの計算

5 については中路言謙氏の論文が当学会誌 ${ }^{8)}$ 上ですで に発表されているので割愛させていただき，1〜4の分 野について最近の数例をとりあげ，説明させていただく こととする。

\section{2. 照明器具配光データの処理}

Westing house 社1では, 道路照明用器具の配光測定 データをIBM Type 704に入力として加え，次の 4 種の データ処理計算を行なっている.

道路の一端で高さHの位監に照明器具を取り付けたと きの

1）定められた方位角と垂直角における光度の計算

2）方位角，垂直角各 $10^{\circ}$ の帯域汇落らる部分光束の 計算

3）道路面上の任意の位置の照度,および道路面上で 道路側および建造物側に対する器具の照明率の計 算

4）道路面上における等照度曲線作成の自動化 などである。

上記の計算には従来約30時間を要したが，計算機を用 いた結果,プログラムが作成されておれば, 計算所要時

$\uparrow$ Exploitation of Electronic Computere for Lighting Calculations.

, 電気陚験所大服支所

正会員栗 岡

第 1 表照明器具訊铪

No. K541054

\begin{tabular}{|c|c|c|c|c|c|c|}
\hline \multirow{2}{*}{ 方位角 } & \multirow{2}{*}{ 垂直角 } & \multicolumn{2}{|c|}{ メータの読み } & \multirow{2}{*}{ 光 } & \multirow{2}{*}{ 光 } & \multirow{2}{*}{ 照 度 } \\
\hline & & A & $\mathrm{B}$ & & & \\
\hline 000 & 005.0 & 2000 & 2000 & 7027.0 & & 07.718983 \\
\hline 005 & 005.0 & 2000 & 2000 & 7027.0 & 018.276 & 07.718983 \\
\hline 015 & 005.0 & 2000 & 1980 & 6991.9 & 018.179 & 07.680388 \\
\hline 165 & 005.0 & 1500 & 1500 & 5270.2 & 013.703 & 05.789237 \\
\hline 175 & 005.0 & 1500 & 1500 & 5270.2 & 013.703 & 05.789237 \\
\hline 180 & 005.0 & 1500 & 1500 & 5270.2 & & 05.789237 \\
\hline
\end{tabular}

Table 2. 1

第 2 表照明器具試駼

\begin{tabular}{|c|c|c|c|c|}
\hline $\begin{array}{l}\text { 人 } \\
\text { 力 } \\
\text { F́ } \\
1 \\
\text { 夕 }\end{array}$ & 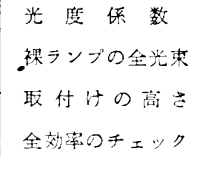 & & $\begin{array}{c}03.5135 \\
052000 . \\
30 . \\
66.50\end{array}$ & $\begin{array}{l}1 \mathrm{~m} \\
\text { feet } \\
\%\end{array}$ \\
\hline & 率 & 道 路 側 & 建造物例 & \\
\hline & 0.5 & 07839.47 & 05664.50 & \\
\hline & 1.0 & 13125.63 & 08873.19 & \\
\hline$m$ & 2.0 & 17170.91 & 11355.65 & \\
\hline & 3.0 & 18409.31 & 12151.02 & \\
\hline \multirow{2}{*}{$(1 \mathrm{~m})$} & 4.0 & 18959.72 & 12523.39 & \\
\hline & 5.0 & 10216.10 & 12710.42 & \\
\hline \multirow{2}{*}{ 照 } & 0.5 & 15.08 & 10.89 & \\
\hline & 1.0 & 25.24 & 17.06 & \\
\hline 明 & 2.0 & 33.02 & 21.84 & \\
\hline \multirow{2}{*}{ 密 } & 3.0 & 35.40 & 23.37 & \\
\hline & 4.0 & 36.46 & 24. 03 & \\
\hline$(\%)$ & 5.0 & 36.95 & 24. 44 & \\
\hline \multirow{3}{*}{$\begin{array}{l}\text { 象 } \\
\text { 限光 } \\
\text { ご束 } \\
\text { と合 } \\
\text { の計 }\end{array}$} & 側 & 19905.50 & 13291.77 & \\
\hline & 上 側 & 00702.65 & 00628.62 & \\
\hline & 全 光 束 $(1 \mathrm{~m})$ & & 034528.53 & \\
\hline$(\operatorname{lm})$ & 計算より求めた全效率 & & $66.40 \%$ & \\
\hline
\end{tabular}

間は13分に短縮される. 最初, 器具の配光測定は手働で あったため, 計算カードへパンチするのに約 1 時間を要 したが, 配光測定の自動化が行なわれ, 測光器の読みが 直接テープ上にパンチされて, 計算機に送られるよ5に なって，迅速化された。 
会雑誌昭和 38 年

印刷されて出てくる計算結果を第 1 表，第 2 表，第 1 図に示す．第 1 表 1 は各方向にお活る測光データ（A， Bは対称点に関するデータ), 光度, $10^{\circ} \times 10^{\circ}$ 带域の部 分光束およびその方向に括ける道路面上の照度を表わし ている．第 2 表は各照明率の計算結果であって, 岕らか じめ入力データとは別に, 光束計で测定された器具効率 （本例では66.50\%）を入れておいて，計算した器具効 率（本例では66.40\%）との一致の程度をチェックした 後, 以後の計算を続行する.

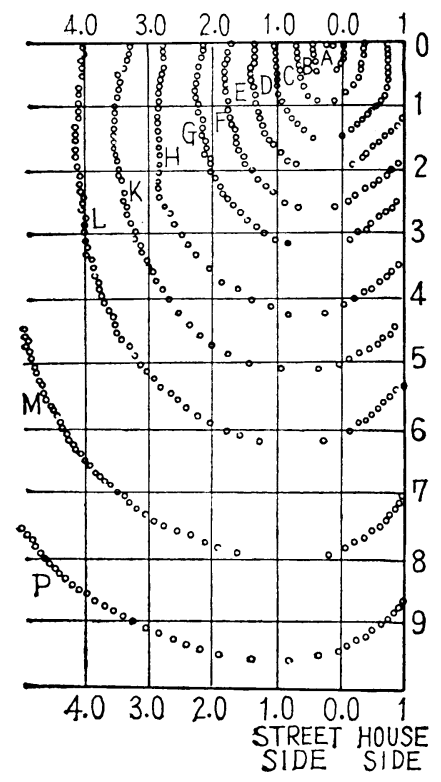

第 1 図部算機がプロットした等照度曲線， 算㨁軸は道路進行方向卧離の高さに 対する比を示す.

漏者过一一現困の縦横の線はそれそれ数字て 畵かれている.たとえば横の 0 線は 0,1 線は1

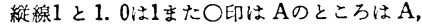
$\mathrm{B}$ のところは $\mathrm{B}$ ，とい5よ5に全部文字で書 かれている，現图では製版上小さくすること が困難なので上揭のよ5にした。

第1図は高さ30フィートに取り付けられた器具による 道路面上の等照度曲線の印刷結果である. この図では照 明器具の取付け高さを基準として, 道路の幅方向の道路 側に取付け高さの 5 倍, 建造物側に 1 倍（それぞれY 軸), 道路進行方向に 10倍 (X軸) 距離によって作られ る頒域の照度分布を示している，X一Y軸それぞれを等 分し， $120^{2}$ 筒の面素について第 1 表の 各方向の照度の 值から, 球座標と直角座標の変換式を使用して照度を計 算していく.

まずX $=0$ の行に対して 120筒管のYの各点で求めら れた照度とあらかじめ指定された照度值（A， B， C…… ‥, Tの15段階まで選びうる.) と比較し, 両者が最も 近い位置に，指定された照度に相当する記号が印刷され
る. 以下 $\mathrm{X}=1,2$, ，120まで同様な操作をくり 返し，等照度曲線が完成れる。

\section{3. 野外照明の設計}

\section{1 道 路 照 明}

N E A C 2203を使用して，計算機の入力として

1) 道路幅 B

2）道路面上の平均照度 $\overline{\mathrm{E}}_{0}$

3）道路面上の照度の均斉度 $[\overline{\mathrm{E}} / \mathrm{E} \mathrm{min}] 0$

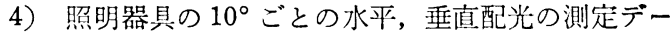
タ I $(\theta, \varphi)$ を与之, 第 2 図に示すような照明器具 の取付け条件に関する要因

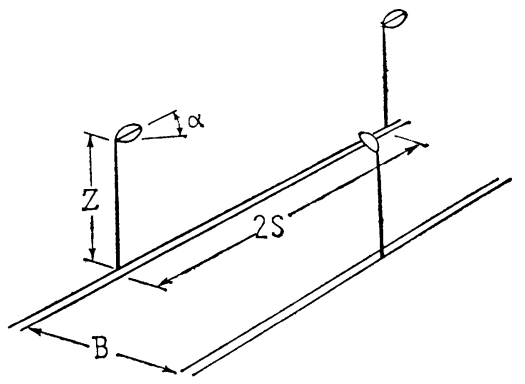

第 2 図

1) 照明器具の取付计時の傾き角 $\alpha$

2) 照明器具の取付け高さ $Z$

3) 照明器具の取付け間隔 $\mathrm{S}$

を出力として決定するようなプログラムが作成されてい $ろ^{2)}$.

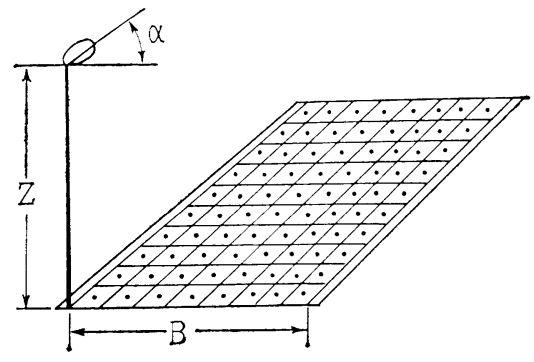

第 3 図

その概要を述べる。最初に，第 3 図のように器具を 1 個だけ，道路の片側に高さZの位置に取り付けた場合を 考える，道路面を仮想的に，長さ方向および幅方向各 1 $\mathrm{m}$ ごとの細かい網目にくぎり，その網目の中心の照度を 逐点的济算する。

まず, 取付け高さの水隻 $Z_{1}$ において器具の傾き角 $\alpha$ の水準を $\alpha_{1} \alpha_{2} \cdots \cdots \cdots, \alpha_{n}$ と順次变化させて, 道路面上 の網目の照度を逐点的汇計算し, その平均照度が最大と なる角度 $\alpha_{o p t}\left(Z_{1}\right)$ を推定する.

そして，最適傾き角 $\alpha_{o p t}$ での道路面の照度パターン 
おっび平均照度 $\mathrm{E}$ を計算し, 道路面上の平均照度が与え られた值 $\overline{\mathrm{E}}_{0}$ になるよう，器具の取付计間隔 $\mathrm{S}\left(Z_{1}\right)$ を 決定する.さらに，先に計算した 1 個の器具の呈する照 度パターンを, $S\left(Z_{1}\right)$ の間隔で重补合わせて, 道路面 上の照度パターンを求的る。

次江取付け高さ $Z$ を水淮 $Z_{2}, Z_{3}, \cdots \cdots \cdots Z_{m}$ と変化さ せて, 同様の方法により, $\alpha_{\mathrm{opt}}\left(Z_{j}\right)$, 取付敄間隔 $\mathrm{S}$ $\left(Z_{j}\right)$, 均斉度 $\left[\overline{\mathrm{E}} / \mathrm{E}_{\mathrm{min}}\right]\left(Z_{j}\right)$ （ただし $j=2,3 \cdots \cdots$

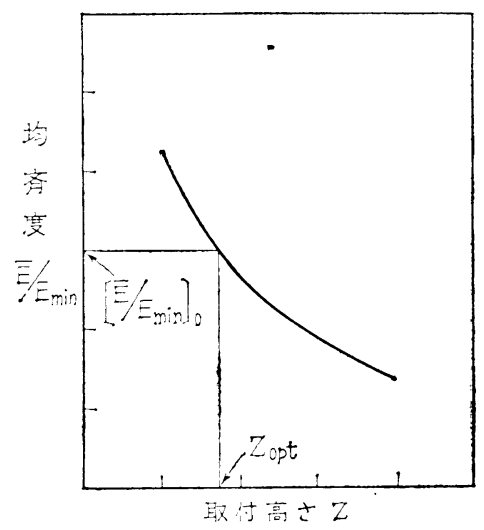

第 4 図

$\cdots, \mathrm{m})$ を計算する.

以上の結果, 均斉度を取付计高さの関倸が第 4 図のよ 了に得られたすると, 次のステップのプログラムによっ

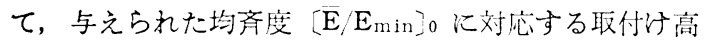
さ $Z_{\mathrm{opt}}$ が内とうされる。 そして最後汇取付许高さを, ここに得られた $Z_{\mathrm{opt}}$ にセットして同㥞の計算を進め,

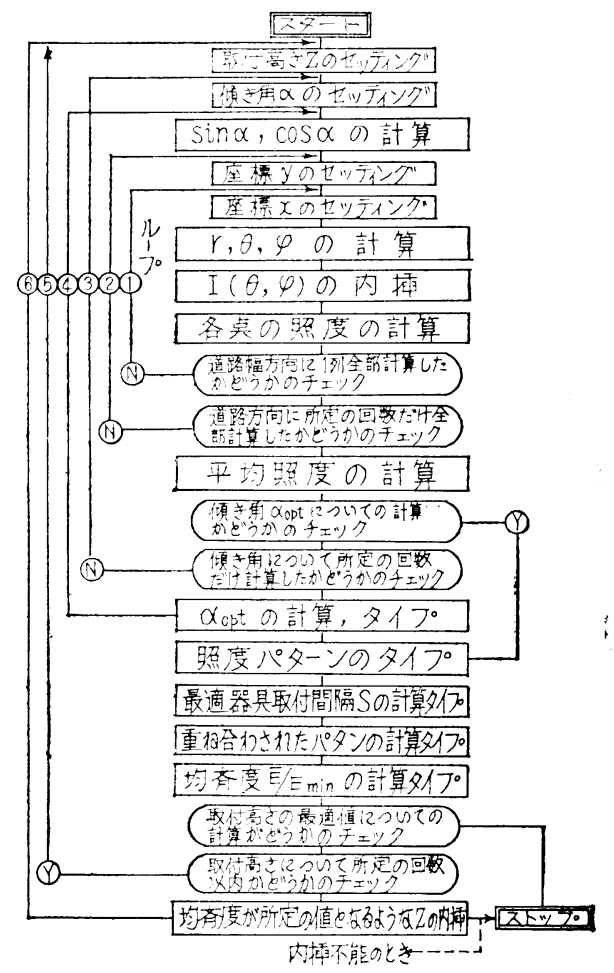

第 5 図フローチ十ート

$\alpha_{\mathrm{opt}}\left(\mathrm{Z}_{\mathrm{opt}}\right), \quad S\left(\mathrm{Z}_{\mathrm{opt}}\right)$ および照度パターンを言算機出 力として得る.

第 5 図は以上のような計算のフローチャートである。

3.2. スポーツ照明

General Electric 社では IBM 704 を使用してフット

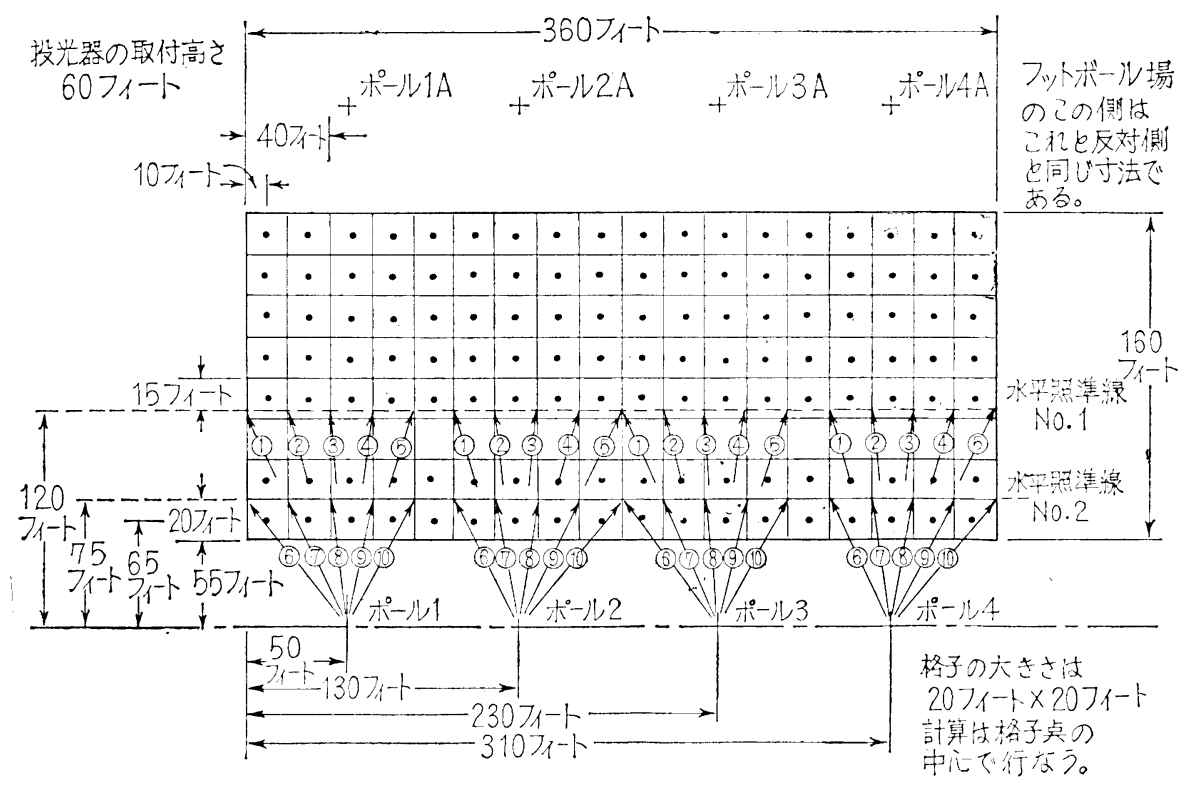

Vol. 47 No. 9 
ボール場の照明計算を行なっている3).

第 6 図のよ5に長さ 360 フィート，幅 160 フィートの フットボール場があり，8本のポールに各10個の照明器 具を取り付ける。フットボール場の長さ方向を18分割， 幅方向を8 分剖して，それぞれの網目の中心の照度を計 算する. 特定の網目の中心の照度は各照明器具よりの照 度の重畳したものであるからその点に関して，すべての 投光器 $(8 \times 10$ 個 $)$ の向きと位睤とから逆二乘法則によ って計算される。

したがってフットボール場の網目 $(8 \times 18$ 個 $)$ の照度 をすべて計算するためには約 1 万回の計算が必要であ る. 一つの器具が一つの網目の中心に呈する照度を計算 するための時間が 0.1 秒とすれば，すべての網目の照度 が計算されるまでに約 25 分を要する.

最初の照度計算が行なわれると，むらのない照明を行 なうために，行間の照度レベルを比較して差がなくなる ように照準点の水平間墖を修正する（もし必要なら，列 間についても同様な計算を行なって修正を行なう). そ の後上記の照度計算を再度くり返す，上記の照度レベル の此が最初の要求ど和りになると, 照度值と投光器の方 向がプリントアウトされる。

\section{4. 室 内 照 明}

\section{1. 相互反射の計算}

P.F. O' Brien は䇪内照明の設計資料として，次のよ うな相互反射の計算を行なっている゙．

第 7 図のよ5に六面体の空の壁 4 面，天井，林各 1 面

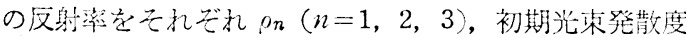

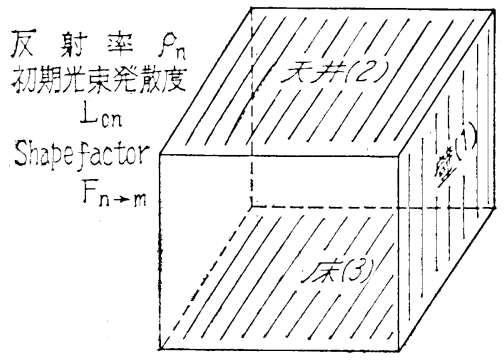

第 7 図室内照明設棓

をL L とすれば，最終光束発散度 $\mathrm{L}_{n}$ は下記の連立方程 式より求められる。

$$
\begin{aligned}
& +\left(1 / \rho_{1}-F_{11}\right)-F_{12}-F_{13} \\
& -F_{12}+\left(1 / \rho_{1}-F_{22}\right)-F_{23} \\
& -F_{31}-F_{32}+\left(1 / \rho_{3}-F_{33}\right)
\end{aligned}
$$

Luminous Transfer Matrix

Response Excitation Vector

$$
\text { Vector }
$$

$$
\mathrm{F}_{i j}=\frac{1}{\pi \mathrm{A}_{i}} \int_{A i} \int_{A j} \frac{\cos \theta i \cos \theta j}{r^{2} i \rightarrow j} d \mathrm{~A} i \cdot d \mathrm{~A} j
$$

で shape factor と呼ばれ，室指数 $\mathrm{K}_{r}$ によって変化す る.上の式でパラメータは $\rho_{1}, \rho_{2}, \rho_{3} F_{11}, F_{12}, \cdots \cdots$, $\mathrm{F}_{33}$ であり，各反夥，窒指数（または shape factor） の異なる䘄々の場合こついて計算を行な5ことは非常に やっかいな問題である。

O'Brien は IBM 704 を使用して

$$
\begin{aligned}
& 0.1 \leqslant \rho_{n} \leqslant 1.0 \\
& 0.05 \leqslant \mathrm{~K}_{r} \leqslant 3.0
\end{aligned}
$$

の範田で $\rho_{n} ， K_{r}$ の 35,000 の組み台わせについて相互 反射による天井，床，壁での光束発散度の変化を計算し て表を作成した，との一例を第 3 表に示す。

第 3 表壁の光束発敬度の变化 $\mathrm{L}_{1} / \mathrm{L}_{01}$ の表であって表 の上側は正方形の窒の場合，下側は無限汇長い廊下の昜 合である.な就定 1 は壁，2 は天井，3 は床を表わす。

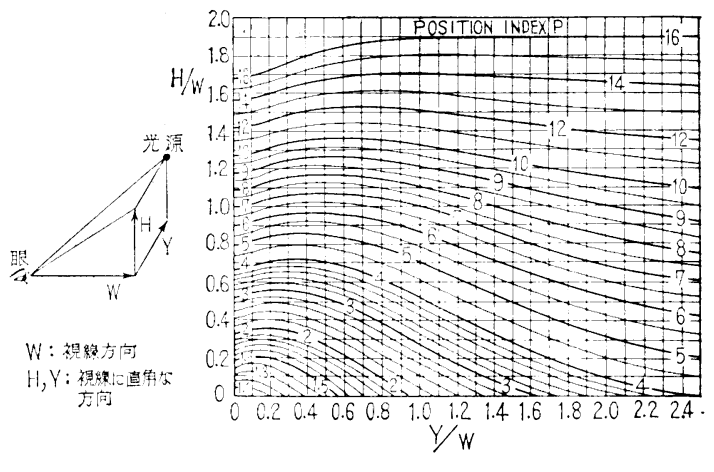

第8図 ポシション・インデックスの因

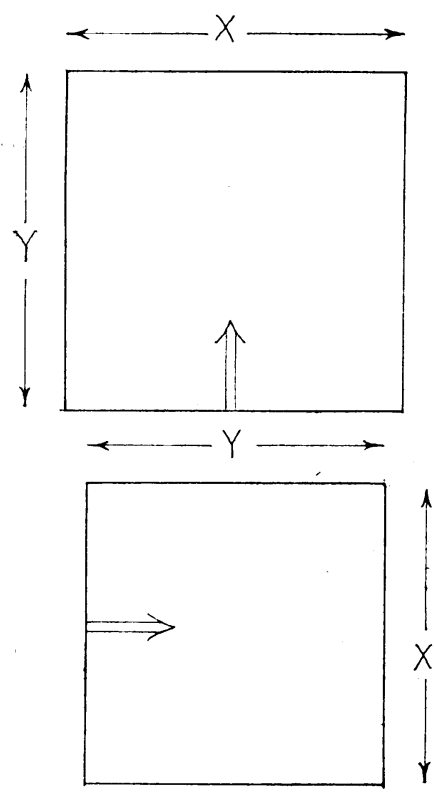

第9 図 器具の取付け間隔はH $\mathrm{X}: 2 \mathrm{H} \sim 12 \mathrm{H} \mathrm{Y}: 2 \mathrm{H} \sim 12 \mathrm{H}$ 
第 3 表壁の光束怒散度の变化 $\mathrm{L}_{1} / \mathrm{L}_{01}$ の表

\begin{tabular}{|c|c|c|c|c|c|c|c|c|c|c|}
\hline$\rho_{2}$ & \multicolumn{3}{|c|}{0.8} & \multicolumn{4}{|c|}{0.7} & \multicolumn{3}{|c|}{0.5} \\
\hline$\rho_{1}$ & 0.8 & 0.5 & 0.3 & 0.1 & 0.5 & 0.3 & 0.1 & 0.5 & 0.3 & 0.1 \\
\hline \multicolumn{11}{|l|}{$\mathrm{k}_{1}$} \\
\hline \multicolumn{11}{|c|}{$o_{3}=0.1$} \\
\hline \multirow{2}{*}{0.1} & 1. 2097 & 1.1215 & 1.0695 & 1. 0222 & 1.1154 & 1.0662 & 1.0211 & 1. 1037 & 1.0597 & 1.0191 \\
\hline & 1. 1765 & 1.1034 & 1.0596 & 1.0191 & 1.0971 & 1.0561 & 1.0180 & 1.0848 & 1. 0.492 & 1.0159 \\
\hline \multirow{2}{*}{0.2} & 1. 3778 & 1. 2058 & 1.1146 & 1.0355 & 1. 1959 & 1.1090 & 1.0339 & 1.1748 & 1. 0980 & 1. 0307 \\
\hline & 1. 3573 & 1.1969 & 1.1095 & 1.0340 & 1. 1856 & 1.1037 & 1.0323 & 1. 1639 & 1.0923 & 1.0290 \\
\hline \multirow{2}{*}{0.3} & 1.5628 & 1.2905 & 1.1561 & 1.0471 & 1.2762 & 1.1492 & 1. 0452 & 1. 2489 & 1. 1358 & 1.0415 \\
\hline & 1. 5364 & 1.2791 & 1.1506 & 1.0456 & 1. 2498 & 1.1363 & 1.0416 & 1.2222 & 1.1224 & 1. 0377 \\
\hline \multirow{2}{*}{0.4} & 1. 7221 & 1. 3551 & 1.1866 & 1. 0553 & 1.3383 & 1.1788 & 1.0532 & 1.3060 & 1.1636 & 1.0492 \\
\hline & 1. 7090 & 1.3500 & 1.1842 & 1.0547 & 1. 3320 & 1.1762 & 1.0526 & 1. 2998 & 1.1606 & 1. 0484 \\
\hline \multirow{2}{*}{0.5} & 1. 8731 & 1.4111 & 1. 2118 & 1.0619 & 1. 3924 & 1.2035 & 1.0597 & 1.3565 & 1.1872 & 1.0555 \\
\hline & 1.8721 & 1. 4107 & 1.2117 & 1. 0618 & 1.3920 & 1.2033 & 1.0597 & 1.3561 & 1.1870 & 1. 0554 \\
\hline \multirow{2}{*}{0.7} & 2.1486 & 1.5017 & 1. 2507 & 1.0716 & 1. 4810 & 1.2420 & 1.0695 & 1.4414 & 1. 2251 & 1. 0652 \\
\hline & 2.1656 & 1.5069 & 1. 2529 & 1. 0721 & 1.4869 & 1. 2445 & 1.0700 & 1.4488 & 1. 2282 & 1.0660 \\
\hline \multirow{2}{*}{1.0} & 2.4980 & 1.5995 & 1. 2901 & 1.0810 & 1.5783 & 1. 2818 & 1.0790 & 1.5377 & 1. 2656 & 1. 0752 \\
\hline & 2.5276 & 1.6070 & 1.2930 & 1.0817 & 1.5874 & 1.2853 & 1.0799 & 1.5495 & 1.2703 & 1. 0763 \\
\hline \multirow{2}{*}{1.5} & 2. 9386 & 1. 7016 & 1. 3287 & 1.0899 & 1. 6823 & 1.3216 & 1.0883 & 1. 6449 & 1.3076 & 1.0851 \\
\hline & 2.9712 & 1. 7084 & 1.3312 & 1.9904 & 1. 6909 & 1.3248 & 1.0890 & 1.6569 & 1. 3122 & 1.0861 \\
\hline \multicolumn{11}{|c|}{$\omega_{3}=0.3$} \\
\hline \multirow{2}{*}{0.1} & 1. 2742 & 1.1514 & 1.0878 & 1.0276 & 1.1446 & 1.0820 & 1.0259 & 1.1251 & 1.0715 & 1.0227 \\
\hline & 1. 2421 & 1.1387 & 1.0788 & 1.0250 & 1. 1274 & 1.0728 & 1.0231 & 1.1071 & 1.0616 & 1.0197 \\
\hline \multirow{2}{*}{0.2} & 1. 4923 & 1. 2597 & 1.1412 & 1. 0430 & 1. 2421 & 1.1324 & 1.0406 & 1. 2098 & 1.1161 & 1.0359 \\
\hline & 1.4729 & 1. 2510 & 1. 1369 & 1,0418 & 1. 2330 & 1.1279 & 1.0393 & 1.1998 & 1.1110 & 1.0345 \\
\hline \multirow{2}{*}{0.3} & 1. 7137 & 1. 3519 & 1.1851 & 1. 0549 & 1.3306 & 1.1752 & 1. 0523 & 1. 2911 & 1.1565 & 1.0472 \\
\hline & 1.6893 & 1. 3423 & 1.1807 & 1. 0537 & 1.3202 & 1.1703 & 1.0510 & 1.2794 & 1. 1508 & 1.0457 \\
\hline \multirow{2}{*}{0.4} & 1.9010 & 1.4209 & 1. 2161 & 1. 0630 & 1. 3971 & 1. 2056 & 1. 0603 & 1.3529 & 1.1853 & 1. 0550 \\
\hline & 1.8890 & 1. 4167 & 1.2143 & 1.0625 & 1.3925 & 1.2035 & 1.0597 & 1. 3474 & 1.1830 & 1.0543 \\
\hline \multirow{2}{*}{0.5} & 2.0726 & 1. 4781 & 1. 2408 & 1.0692 & 1.4529 & 1.2300 & 1.0665 & 1. 4059 & 1. 2095 & 1.0613 \\
\hline & 2. 0717 & 1. 4778 & 1.2407 & 1.0691 & 1. 4526 & 1.2299 & 1.0665 & 1. 4054 & 1. 2093 & 1.0612 \\
\hline \multirow{2}{*}{0.7} & 2. 3733 & 1.5666 & 1. 2771 & 1. 0780 & 1.5406 & 1.2667 & 1.0755 & 1.4917 & 1. 2465 & 1.0706 \\
\hline & 2. 3883 & 1.5706 & 1.2787 & 1.0783 & 1.5454 & 1.2686 & 1.0759 & 1.4978 & 1. 2491 & 1.0712 \\
\hline \multirow{2}{*}{1.0} & 2. 7365 & 1.6573 & 1. 3123 & 1.0862 & 1.6325 & 1.3029 & 1.0840 & 1.5853 & 1. 2846 & 1.0797 \\
\hline & 2. 7621 & 1.6631 & 1.3145 & 1. 0867 & 1.6397 & 1.3056 & 1.0846 & 1.5951 & 1. 2884 & 1. 0806 \\
\hline \multirow{2}{*}{1.5} & 3.1726 & 1. 7483 & 1. 3455 & 1. 0936 & 1. 7269 & 1. 3379 & 1.0919 & 1. 6857 & 1. 3220 & 1.0886 \\
\hline & 3. 2003 & 1. 7535 & 1. 3473 & 1.0940 & 1. 7337 & 1.3403 & 1.0925 & 1.6955 & 1. 3265 & 1. 0894 \\
\hline
\end{tabular}

\subsection{Glare の計算}

これからの窝内照明の設計には，これまでの照度の問 題以外に照明の快適性をも考虑寸る必要がある，二のた めには光源によるまぶしさを計算して，これを小さな值 に执さえるような設計をしなければならない。

英国の IES 5) 6)ではまぶしさの䑩価式として，

$$
\mathrm{G}=\sum_{\text {光源数 }} \frac{\mathrm{B}_{s^{1}}{ }^{1.6}}{\mathrm{~B}_{b}}{ }^{\omega^{0.8}} \times \frac{1}{\mathrm{P}^{1.6}}
$$

を採用し，電子尌算機を用いて光源が格子状に規則的に
配列された場合の Glare index の奏を作成している。こ こで $\mathrm{B}_{s}$ は光源の光束発频度（フート・ランベルト）, $\mathrm{B}_{b}$ は背景の光束発敬度(フート・ランベルト)，（は目か ら光源を見込む立体角，P法ボション・インデックス と呼ばれ，视野のどの点に光源が㐬るかによって乘ずる 第8図のような隹の重みである.

上の計算は光源の数ボ多くなると韭常にやっかいにな る。

IES では第 9 図のように，視線の方向の大きさ $\mathrm{Y}$, 
第 4 表 Glare Index 計算例

$I \propto \cos ^{4} \theta$

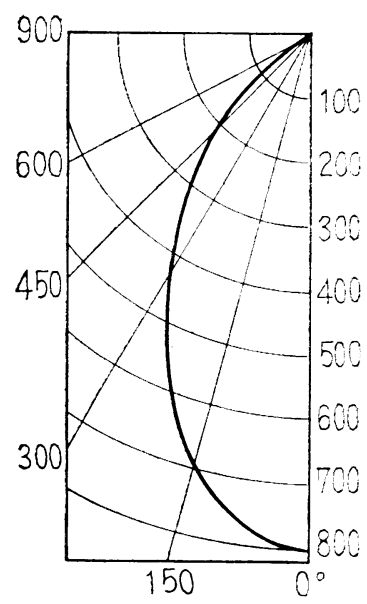

器具の配光曲線

\begin{tabular}{|c|c|c|c|c|c|c|c|c|c|c|c|c|c|c|c|c|}
\hline \multirow{2}{*}{$\begin{array}{l}上 \\
\text { 上 }\end{array}$} & \multirow{2}{*}{$\begin{array}{l}\text { 側 } \\
\text { 例 }\end{array}$} & \multicolumn{10}{|c|}{ 器具からの光架の出方 } & & & & & \\
\hline & & \multicolumn{4}{|c|}{$0 \%$} & & \multicolumn{5}{|c|}{$25 \%$} & \multicolumn{5}{|c|}{$50 \%$} \\
\hline & & & & & & & 类面 & 面i の & 及 & 射率 & & & & & & \\
\hline \multirow{3}{*}{\multicolumn{2}{|c|}{$\begin{array}{c}\text { 天非 } \\
\text { 缽 } \\
\text { 床 }\end{array}$}} & 70 & 70 & 50 & 50 & 30 & 70 & 70 & 50 & 50 & 30 & 70 & 70 & 50 & 50 & 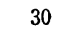 \\
\hline & & 50 & 30 & 50 & 30 & 30 & 50 & 30 & 50 & & 30 & 50 & 30 & 50 & 30 & 30 \\
\hline & & 14 & 14 & 14 & 14 & 14 & 14 & 14 & 14 & & 14 & 14 & 14 & 14 & 14 & 1 \\
\hline \multicolumn{2}{|c|}{ 室の大きさ } & \multicolumn{15}{|c|}{ Glare index } \\
\hline \multirow{6}{*}{$2 \mathrm{H}$} & $2 \mathrm{H}$ & 12.4 & 14.6 & 12.8 & 14.8 & 15.0 & 9.7 & 11.4 & 10.6 & 12.2 & 13.3 & 7.0 & 8.3 & 8.2 & 9.5 & 11.1 \\
\hline & $3 \mathrm{H}$ & 12.6 & 14.6 & 13.0 & 14.8 & 15.2 & 9.8 & 11.3 & 10.7 & 12.2 & 13.3 & 7.1 & .3 & 3 & 9.6 & 11 \\
\hline & $4 \mathrm{H}$ & 12.7 & 14.5 & 13.2 & 14.8 & 15.3 & 9.9 & 11.3 & 10.9 & 12.2 & 13.4 & 7.1 & 8.1 & 3 & 9.4 & 11.1 \\
\hline & & \begin{tabular}{ll|}
12.7 \\
\end{tabular} & 14.4 & 13.2 & 14.8 & 15.2 & 9.9 & 11.3 & 10.9 & 12.2 & 13.4 & 7.0 & 8.1 & 8.3 & 9.3 & 11.0 \\
\hline & $8 \mathrm{H}$ & 12.8 & 14.3 & 13.3 & 14.7 & 15.0 & 9.9 & 11.0 & 10.9 & 12.2 & 13.2 & 6.9 & 7.3 & 8.2 & 9.2 & 10.8 \\
\hline & $12 \mathrm{H}$ & 12.8 & 14.2 & 13.3 & 14.6 & 15.0 & 9.8 & 10.9 & 10.9 & 12.0 & 13.1 & 6.8 & 7.7 & 8.1 & 9.0 & 10. \\
\hline \multirow{6}{*}{$4 \mathrm{H}$} & $2 \mathrm{H}$ & 12.7 & 14.5 & 13.2 & 14.8 & 15.2 & 9.9 & $\begin{array}{ll}9 & 11.2\end{array}$ & 10.9 & 12.1 & 13.3 & 7.0 & 8.0 & 8.3 & 9.3 & 11. \\
\hline & $3 \mathrm{H}$ & 13.0 & 14.5 & 13.5 & 15.0 & 15.4 & 10.1 & 111.2 & 11.1 & 12.2 & 13.5 & 7.1 & 8.0 & 3 & 9.4 & 11. \\
\hline & $4 \mathrm{H}$ & 13.1 & 14.3 & 13.6 & 14.8 & 15.3 & 10.1 & 111.0 & 11.1 & 12.0 & 13.3 & 7.1 & 7.7 & 4 & 9.2 & 10 \\
\hline & $6 \mathrm{H}$ & 13.1 & 14.3 & 13.6 & 14.8 & 15.3 & 10.1 & 10.9 & 11.1 & 12.0 & 13.2 & 7.1 & 7.6 & 8.4 & 9.1 & 10 \\
\hline & $8 \mathrm{H}$ & 13.2 & 14.2 & 13.7 & 14.6 & 15.3 & 10.2 & 210.8 & 11.3 & 11.9 & 13.1 & 7.1 & 7.6 & 8.4 & 9.0 & 10. \\
\hline & $12 \mathrm{H}$ & 13.2 & 14.1 & 13.7 & 14.6 & 15.2 & 10.1 & $1 \quad 10.7$ & 11.2 & 11.9 & 13.0 & 7.0 & 7.5 & 8.3 & 8.9 & 10.5 \\
\hline \multirow{4}{*}{$8 \mathrm{H}^{\prime}$} & $4 \mathrm{H}$ & 13.1 & 14.2 & 13.7 & $14.6^{\prime}$ & 15.0 & 10.1 & 10.8 & 11.1 & 11.9 & 13.1 & 7.1 & 7.6 & 8.4 & 9.0 & 10.6 \\
\hline & $6 \mathrm{H}$ & 13.1 & 14.0 & 13.7 & 14.5 & 15.2 & 10.1 & 10.7 & 11.2 & 11.8 & 13.1 & 7.1 & 7.6 & 8.4 & 8.9 & 10. \\
\hline & $8 \mathrm{H}$ & 13.2 & 13.9 & 13.8 & 14.5 & 15.2 & 10.1 & 10.6 & 11.2 & 11.8 & 13.0 & 7.0 & 7.5 & 8.3 & 8.9 & 10.5 \\
\hline & $12 \mathrm{H}$ & 13.1 & 13.8 & 13.7 & 14.3 & 15.1 & 10.0 & 10.4 & 11.1 & 11.6 & 13.0 & 6.9 & 7.3 & 8.2 & 8.8 & 10. \\
\hline \multirow{4}{*}{$12 \mathrm{H}$} & $4 \mathrm{H}$ & 13.2 & 14.1 & 13. 7 & 14.6 & 15.2 & 10.1 & 10.7 & 11.2 & 11.9 & 13.0 & 7.0 & 7.5 & 8.3 & 8.9 & 10.5 \\
\hline & $6 \mathrm{H}$ & 13.2 & 13.9 & 13.8 & 14.5 & 15.2 & 10.1 & 10.6 & 11.2 & 11.8 & 13.0 & 7.0 & 7.4 & 8. 3 & 8.8 & 10. \\
\hline & $8 \mathrm{H}$ & 13.1 & 13.8 & 13.8 & 14.3 & 15.1 & 10.0 & 10.4 & 11.1 & 11.7 & 13.0 & 6.9 & 7.3 & 8.2 & 8.8 & 10.4 \\
\hline & $12 \mathrm{H}$ & 13.1 & 13.7 & 13.8 & 14.2 & 15.1 & 10.0 & 10.4 & 11.1 & 11.6 & 12.9 & 6.9 & 7.3 & 8.2 & 8.7 & 10. \\
\hline
\end{tabular}

幅方向の大きさ Xの室に, 10種㓥の配光を有する照明器 具をX. Y 方向それぞれ間隔 $\mathrm{H} て ゙$ 配列し，矢印のよう な位置と方向欴視があるときの Glare index を求め ている.ここでHは目の高さから器具をでの取付け高さ であり，Xとして $2 \mathrm{H} か ら 12 \mathrm{H}$ ．Yとして $2 \mathrm{H} か 12 \mathrm{H}$ の組み合わせ汶対して表が作成されている，その一例を 第 4 表 ${ }^{6}$ 亿示す. この表では表の左側の図のよ5な配光 を有する器具について, 天井, 壁, 床の種々の反射䜌, 種々の室の大きさに対する Glare indexが与えられてい る.

この計算では視線の方向が水平かつ，中览方向であ り，今後は室の中で任意の位置にある観测者が任意の方 向に対する Glare index を計算する必要がある。また 上記の計算では北景の光束発散度が一様と考学ている が, 背景の光束発散度が一㥞でないときの奏效光束発散 度の推定のしかたも今後の問題であらう。

\section{5. 色彩の計 算}

アメリカのN B S では, 1) 分光測光のデータから
$\mathrm{CIE}$ 色度座標 $x, y, \mathrm{Y}$ への変換のブログラミングおよ び，2） I 11 “C” において色度座標 $x, y$ ， Yをマンセ ル記号H V C 湾換するプログラミングを作成した，最 近の交献》によれば後者のマンセル記号変換のプログラ ミングが紹介されている.

この問題は数学的に不連続な格子点に対して，3次元 対 3 次元の座標変換の問題である. 格子点の数は約 5,000 もあり, 内とうに用いる格子点を探し出すため化, 経済 的なスキャンニング・ルーティンを工头することが最す 大きい問題で京り，ベクトル代数を使用してこの点を解 決している.

マンセル系 $\mathrm{H}, \mathrm{V}, \mathrm{C}$ CIE 系 $x, y, \mathrm{Y}$ との間には 次のような関倸がある。

$$
\begin{aligned}
& \mathrm{Y}=\mathrm{f}_{1}(\mathrm{~V}) \\
& x=\mathrm{f}_{2}(\mathrm{H}, \mathrm{V}, \mathrm{C}) \\
& y=\mathrm{f}_{3}(\mathrm{H}, \mathrm{V}, \mathrm{C})
\end{aligned}
$$

関数 $f_{2} ， f_{3}$ 江観测者汇よる也空間の評価と分光测定 との比較によって得られたものである。 $f_{1}$ については OSA のマンセル空間の委員会によって，次のような多 
項式が採用されている。

$$
\begin{aligned}
\mathrm{Y}= & \mathrm{f}_{1}(\mathrm{~V})=1.2219 \times 10^{-2} \mathrm{~V}-2.3111 \times 10^{-3} \mathrm{~V}^{2} \\
& +2.3951 \times 10^{-3} \mathrm{~V}-2.1009 \times{ }^{-4} \mathrm{~V}^{4} \\
& +8.404 \times 10^{-6} \mathrm{~V}^{5} \quad \ldots \ldots \ldots \ldots \ldots \ldots \ldots \ldots \ldots \ldots \ldots \ldots \ldots \ldots
\end{aligned}
$$

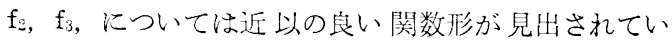
ない，っしてこれら二つの関数関係は $(\mathrm{H}, \mathrm{V}, \mathrm{C})$ 空間 に㤁いて 4.996 点の格子点についてだけ判明している.

\section{1 マンセルバリューV の求め方}

与总られたY詨して（2）式を満足するVの值を次

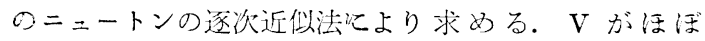
$\sqrt{\mathrm{Y}}$ に比例するので初期值 $\mathrm{V}_{0}$ は

$$
\mathrm{V}_{0}=10 \sqrt{\mathrm{Y}}
$$

として学完る。

\section{2 マンセルヒュー H とクロマ $\mathrm{C}$ の求め方}

マンセルVが求まると次の数列より $\mathrm{V}_{1} \leq \overline{\mathrm{V}} \leq \mathrm{V}_{2}$ を满 足乙, $\overline{\mathrm{V}}$ 汇最毛近い $\mathrm{V}_{1}, \mathrm{~V}_{2}$ を求める.

$$
0.2,0.4, \cdots \cdots, 1.0,2.0, \cdots \cdots, 9.0,10.0 \cdots \cdots
$$

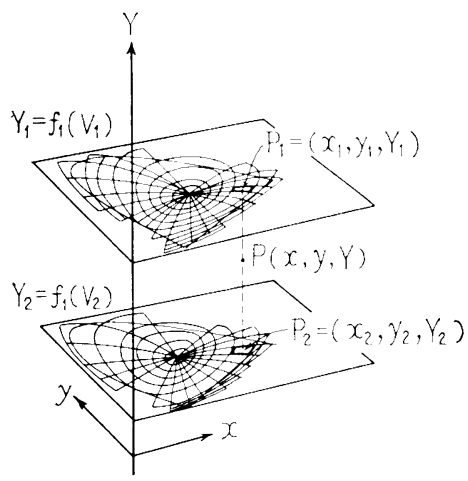

第 10 図

第10図のよ5に与えられた点を $\mathrm{P}(\bar{x}, \bar{y}, \overline{\mathrm{Y}})$ として $(x, y)$ 平面记平行な二つのデータ平面 $\mathrm{Y}_{1}=\mathrm{f}_{1}\left(\mathrm{~V}_{1}\right)$ と $\mathrm{Y}_{2}=\mathrm{f}_{1} \mathrm{~V}_{2}$ への投射点それぞれ $\mathrm{p}_{1}, \mathrm{p}_{2}$ とする，二つ の投刍点のマンセル記号 $\left(\mathrm{H}_{1}, \mathrm{~V}_{1}, \mathrm{C}_{1}\right),\left(\mathrm{H}_{2}, \mathrm{~V}_{2}, \mathrm{C}_{2}\right)$ を承わるこどできると $\mathrm{P}$ 点のマンセル記号は

$$
\begin{aligned}
& \overline{\mathrm{H}}=\mathrm{H}_{1}+\frac{\overline{\mathrm{V}}-\mathrm{V}_{1}}{\mathrm{~V}_{2}-\mathrm{V}_{1}}\left(\mathrm{H}_{2}-\mathrm{H}_{1}\right) \\
& \overline{\mathrm{C}}=\mathrm{C}_{1}+\frac{\overline{\mathrm{V}}-\mathrm{V}_{1}}{\mathrm{~V}_{2}-\mathrm{V}_{1}}\left(\mathrm{C}_{2}-\mathrm{C}_{1}\right)
\end{aligned}
$$

なるリニア補間で求められる.

し江がって間題は与光られた点 $\mathrm{b}(x, y)$ の足点 $\mathrm{P}_{1}$

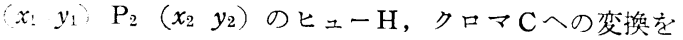
行标名是いことになる。第 11 図は $\mathrm{V}_{n}=2.0$ の場合の

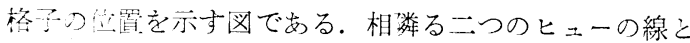
クトマの線でくぎられる無数の四辺形を考えると, 点 $\mathrm{P}$ $\{x, y\}$ : れららの四辺形の中の一つに含まれているは オ゙でるる.どの四辺形沉属するかを探し出すことができ れば，ての四辺形の四寸みの座標から，P点のマンセル

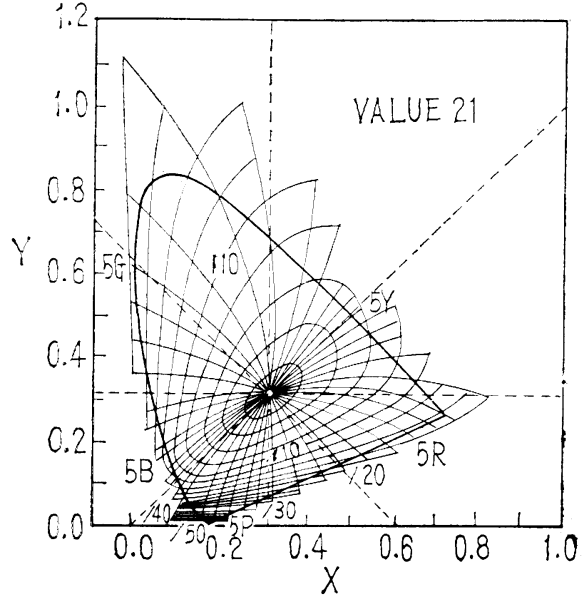

第 11 図

記号 $\mathrm{H}$ とを求めることができる.

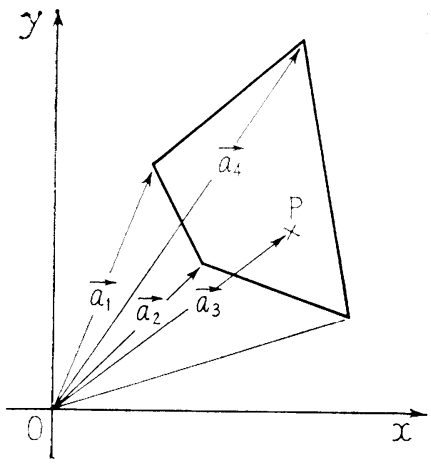

第 12 図

四辺形中にP点が含まれているかどうかのチェックは ベクトル算法によって行な5。第12図に打いて四辺形の 各項点と原点 0 と結ぶベクトル $\overrightarrow{a_{1}}, \overrightarrow{a_{2}}, \overrightarrow{a_{2}}, \overrightarrow{a_{4}}$ のスカ ラ一積

$$
\begin{aligned}
& S_{1}=\left(a_{2}-a_{1}\right) \perp\left(X-a_{1}\right) \\
& S_{2}=\left(a_{3}-a_{2}\right) \perp\left(X-a_{2}\right) \\
& S_{3}=\left(a_{4}-a_{3}\right) \perp\left(X-a_{3}\right) \\
& S_{4}=\left(a_{1}-a_{4}\right) \perp\left(X-a_{4}\right)
\end{aligned}
$$

を計算する。（記号」はスカラー積を表わす。）ただし $\mathrm{X}=\{x, y\}$ 項点の座標が $(x, y)$ である任意ベクトル である。四辺形が点 $(x, y)$ を含もとき汇

$$
\mathrm{S}_{k} \mathrm{ZO}(\mathrm{k}=1,2,3,4)
$$

である。

$\mathrm{P}$ 点が含まれている四辺形を見出すためのスキャンニ

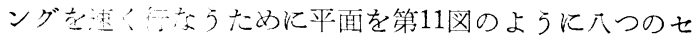
クトルにうっ，まずP点が含まれているセクトルを探し 出子、このセクトルについて，第13図のよ5にまず， = エートラルポイントと 1 番目と 2 番目のヒュ一の線の各 ト 1 番目の点で構成される三角形 $Q_{1}$ を作る. この三角 


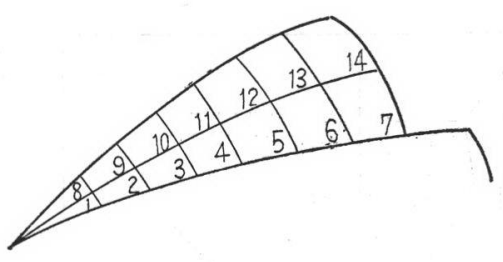

第 13 図

形についてベクトル計算により $\mathrm{P}$ 点がこの三角形中に含 まれているか否かのチェックをする。もし含まれないと きは, 1 番目と 2 番目のヒニーの線の 1 番目と 2 番目の 点でもって四辺形 $\mathrm{Q}_{2}$ が作られ, 点 $\mathrm{P}$ を含むか否かのチ エックをする。

以下順次同様にくり返し, このヒューの線の端まで行 なってる，点 $\mathrm{P}$ を含む $\mathrm{Q}_{j}$ が見つからないときには第 2 第 3 のヒューの線を使って同様にくり返す．点 $\mathrm{P}$ を含む $\mathrm{Q}_{j}$ が見つかると $\mathrm{Q}_{j}$ の四すみの点からリニア補間で点 $\mathrm{P}$ または $\mathrm{P}_{2}$ の, Cが求められ, (5) 式より点 $\mathrm{P} の \overline{\mathrm{H}}$. Vが求められる。

\section{6. おおりに}

電子計算機が現われてから，すでにかなりの年月が経 過しているので，以上ご説明したほかにも，たとえば黒 沢凉之助氏の色彩相互反射の計算など，種々の計算が行 なわれていることと思うが，最近の代表的な利用例だけ
あけ゚てご参考に供した. 今後電子計算機の普及ととも に, わが国でも照明計算に電子計算機が利用されること がしだいに多くなることと思う。

\section{参 考 文 献}

(1) G. A. Horton and P. A. Zaphyr : "Automatic Processing of Photometric Test Data for Street Lighting Luminaires", [I. E. 53-6(1958)341 351]

(2) 栗岡, 佐土根, 宮脇, 岡田滦か：“電子計算機に よる高速道路の照明設計”照学誌 47-3 (1963) $82 \sim 86$.

(3) A. B. Gough : "Programming the IBM 704 Computer", I. E. 55-4，（1960）203～214 または 正木光氏の文献紹介 : 照学誌 45-1 (1961) 33〜35.

(4) P. F. O'Brien: "Lighting Calculations for 35, 000 Rooms”,, I. E. 55-4 (1960) 215 226

(5) I.E. S. Technical Comittee : “The Development of the IES Glare Index System" Trans. IES 27-1 (1962) $9 \sim 26$.

(6) I. E. S. Code 1961 17

(7) W. C. Rheivbolt and J. P. Menard : "Mechanized Conversion of Colorimetvic Data to Munsell Renotation", J. O.S. A. 50-8 (1960) 802.

（8）中路幸謙：照学誌 40-11（1956）495～498

\section{照明界のトピックス}

\section{中 部 電 力主 催 の}

\section{庭 園 灯 展 示会 開 催}

今夏は中部電力各支店 (社)とも, 照明関係需用開拓の 一環として「庭園灯展」が開催された。

早い地区は 6 月上旬から始められ, 夏まつりとか, 七 夕まつりなど，その地方の催事にあわせて開催され，た いへん効果的であった。

現在までに全社管内22会場で延べ142日間780余基の展 示が行なわれ, 約 76 万 5 千人の参観を得, 約 2,00 基の 購入申込みやあっせんがあった。

今年は庭園灯の種類もポール形から, 置形, とうろち 形. ペンダント形などと変化に富み, 旅館, 料亭はもと より，一般家庭て和いても手がるに点灯できるところか

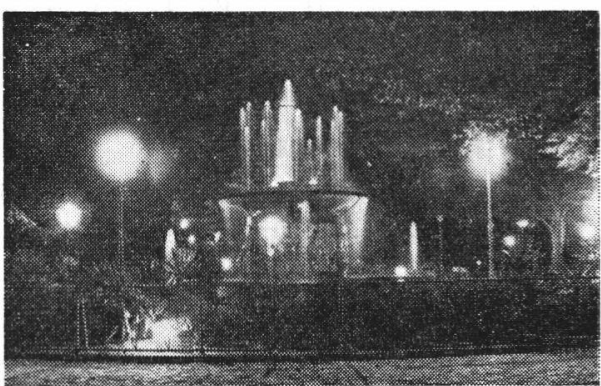

7 月27日より1カ月間にわたり名古屋東山動物園におい て行なわれた庭園灯照明総合展

ら団地の前庭などをはじめとして，へやの一部としての 庭の利用度が高まり, 今後ますをす需用の伸びが期待さ れる. 